\title{
John Hans Menkes (1928-2008)
}

Deaths are always painful - for the spouse and family, for friends and colleagues, and most of all, for the departed anticipating the end of life. On 22 November 2008 in Los Angeles, California, one month short of his 80th birthday, the world of paediatric neurology lost an icon and one of its contemporary fathers. The World at large lost a true Renaissance Man - physician; scientist; playwright; philosopher; connaisseur of good literature, art, music and food; he was a humanist and liberal thinker who deplored discrimination, intolerance, prejudices and false values of all types. The life he lived was as interesting and inspiring as were his contributions to paediatric neurology and his understanding of the world around him, both medical and social. He succumbed to cancer and complications of chemotherapy, hoping until the end to live just one more year, to enable him to complete the 8th edition of his classical textbook of child neurology, to finish a novel he was writing based on the life of the operatic composer Puccini and, most of all, to have a little more time to spend with his loving wife Myrna. Alas he was not given the reprieve he sought.

John Menkes was born on 20 December 1928 in Vienna, Austria, to become the fourth generation of physicians in his family. As a preteen, he spent years of discrimination and racism for being Jewish and even survived for several months in hiding from the Nazis by a kind Viennese family who risked their own lives in so doing. On 11 March 1938 Hitler took over Austria and Austrian citizenship was revoked from all Jewish citizens. In 1939, just days before the German invasion of Poland that initiated World War II in Europe, John and his parents were fortunate to be able to leave Austria. They went to Ireland, where John attended school. The rest of his family that remained in Austria perished. He was eventually able to immigrate to the U.S. and graduate high school in California. He then earned a B.S. and M.S. degree in organic chemistry at the University of Southern California and attended medical school at Johns Hopkins University in Baltimore. He was there exposed to some of the early paediatric neurologists, including Frank Ford, Frank B. Walsh and Sir Charles Simmons. During his paediatric internship and residency at Boston Children's Hospital, he was able to work under William Lennox, Bronson Crothers and Richard Payne. While still an intern he clinically described maple syrup urine disease, but was not able to biochemically define the disease until he encountered another patient during his paediatric neurology residency at Johns Hopkins University.

His return to John Hopkins to study psychiatry was interrupted by conscription into the U.S. Armed Forces during the Korean War. In 1957 he began a paediatric neurology fellowship at the New York Neurological Institute of Columbia University under the direction of Sidney Carter and H. Houston Merritt. He continued his biochemical studies as well, with further description of another case of maple syrup urine disease and also described a form of tyrosinosis and X-linked kinky hair disease, later to bear his eponym and initiating a lifelong interest in disorders of copper metabolism. Returning to Johns Hopkins, he pursued more clinical training in paediatric neurology under the tutelage of David Clark. In 1966 he was offered a faculty appointment at UCLA as the first Head of a new Division of Paediatric Neurology. There he spent the rest of his long career, actively practicing, taking call on the paediatric neurology service, teaching and also maintaining a small private practice until almost the end of his life despite a serious chronic illness.

John was an ideal role model for me and my generation as much as for our younger colleagues and trainees. His patience and firm but gentle manner with patients, especially developmentally delayed children with behavioural disorders, and also with cantankerous colleagues, were legendary. He was always smiling. Never did he become overtly angry or rant against offences, medical errors of others or even the most blatent social injustices, instead quietly pointing out their irrationality and unfairness. Despite what he and his family had 
suffered at the hands of a Nazi Austrian government in his childhood, when offered his Austrian citizenship back more than a half-century late, he graciously accepted it to become a dual U.S. and Austrian citizen and he even accepted an invitation to lecture at the University of Vienna Medical Faculty, to demonstrate that old wounds might heal and that the present generation not be blamed for crimes of the previous. Such was the generosity and lack of resentfulness of this man.

I first met John Menkes in Toronto in 1975, at the first congress of the new International Child Neurology Association (ICNA), a meeting organized by the late Dr. John Stobo Pritchard of The Hospital for Sick Children in Toronto, a father of Canadian paediatric neurology and a founder of ICNA. I was at that time barely two years out of training and in my first academic post. I was impressed that Dr. Menkes preferred to discuss my modest poster than to talk about his own work. Here was a man with sincere humility and genuine interest in others, a quality of generosity, colleaguiality and appreciation for his peers shared by a few other truly great individuals of the 20th century, such as Albert Einstein. He continued to follow my career from that time, offering professional advice upon occasion, but only if asked. We became close friends and colleagues despite our generation gap. It was a great personal honour to be invited by John Menkes in 1998 to co-edit the 6th edition of his textbook and subsequent editions; an even greater honour was John's friendship. He recruited me in 2001 to become his successor as Head of the Division of Paediatric Neurology at Cedars-Sinai Medical Center, with academic appointment at UCLA; it pained John greatly that I returned to Canada in 2004, and he regretted that he had encouraged me to come to an institution that in the end kept few of its promises to enable me to develop academic paediatric neurology and neuropathology. John was always more concerned about the feelings and opportunities of his colleagues, especially the younger ones, than about his own sentiments. John was neither selfish nor competitive: he celebrated the successes of others, especially those of his colleagues and trainees, rather than feeling jealous. His scientific and medical publications, both original peer-reviewed articles and invited reviews and textbook chapters, number more than 200, but perhaps he is best known for his classical textbook, "Child Neurology", the first edition published in 1974. The 8th edition, still in preparation at the time of his death, will be published posthumously. He was too modest to accept my suggestion that it be renamed "Menkes' Textbook of Child Neurology" during his lifetime.

John had a facility with languages and saw them as a key to appreciating different cultures. His mother tongue was German. Though he did not learn English until adolescence, he acquired an eloquence and a vocabulary that would have made any highly educated anglophone proud. He also had a facility with Hebrew and French and he understood some Spanish and Italian. This admirable trait of his easy transition from one language to another remained a very European part of his personality.

John had a special admiration for Canada. Just at the end of the Korean War, from 1954-1956 he was stationed at Pepperrell U.S. Air Force Base Hospital in St John's, Newfoundland (in a NATO-like agreement), where he was head of the Paediatric Service. Professionally, he later visited Canada many times to attend neurological meetings and as a visiting professor. In the early 1970s, while a visiting professor at The Hospital for Sick Children, he was being shown a biochemistry/metabolic research wing when investigators and technologists left their labs to line up along the corrridor. Not realizing how respected he was, Dr. Menkes innocently asked why all of these people were standing in the hall. "Why, they are here to see you, Professor Menkes," and they began shaking his hand in turn. In November 2006 he was the distinguished Sam Darwish Memorial Lecturer at the Alberta Children's Hospital and University of Calgary, speaking on "Disorders of copper metabolism in the developing brain". Despite his broad knowledge internationally of health care systems, he most admired the Canadian single payer (government) system because of its fairness, universality without regard to economic status and the Canadian constitutional definition of health care as a "basic human right", rather than as a business or for-profit service. He also admired Canada as the leading social democracy in the Americas and for the courage to refuse to participate with the U.S. in the Vietnam and Iraq wars, which he considered cruel and useless. Two years before his death, he was investigating the possiblity of moving to Vancouver with an appointment at UBC. He also participated in congresses in Mexico and Latin America where he was well known and admired.

Apart from his medical and scientific contributions, John Menkes had the capacity to contribute to literature. He was a published playright and I had the privilege of seeing one of his plays publically performed in live theatre in Los Angeles. His novels and plays include titles, "The Angry Puppet Syndrome" (a story about adverse effects of a medication and how they affect people's lives), "After the Tempest" (a play about opposing sentiments amongst Jews in Vienna just after the War), "The Last Inquisitor" (about the holocaust) and "Views of Fuji" (a love story about a man who developed cancer). He owned a house in Wales, where he used to isolate himself 3-4 months annually to do his creative non-medical writing. He was a voracious reader and a master chess player as well. He loved wildlife and was especially fascinated by whales.

John contributed to a variety of charitable and philanthropic organizations, and was most involved with Medecins sans Frontiers (Doctors without Borders), World Wildlife Federation and CalArts, a college for art students. He was devoted to his loving wife Myrna and she had enjoyed his reading poetry to her in the evenings. She remained equally devoted to him and supported him caringly throughout his final chronic illness.

One of the highlights of my own life is to have known this gentle, patient, authentic, sincere and brilliant man and to have been inspired by his life and work. The World, our discipline of paediatric neurology and I personally miss him greatly and remember him fondly. Within paediatric neurology, his name is forever indelibly inscribed.

Harvey B. Sarnat Calgary, Alberta, Canada

An autobiography written by Dr. John Menkes was published in the Journal of Child Neurology 2001;16:191-8.

\section{Disclosure}

Portions of this eulogy were taken from Dr. Sarnat's obituary that is being published in the Journal of Child Neurology, and are here reproduced with the permission of Dr. Roger Brumback, Editor of the JCN. 